\title{
Singa Sandelin
}

\section{Työnohjaus ihmissuhdeammateissa oppimisprosessina}

\begin{abstract}
Sandelin, Singa 1986. Työnohjaus ihmissuhdeammateissa oppimisprosessina. Aikuiskasvatus 6, 2, 71-79. - Artikkelissa tarkastellaan klassisen työnohjauksen (supervision) käsitettä ja sisältöä ammatillisen identiteetin kasvun välineenä. Työnohjauksen leviäminen muillekin kuin hoitotyön alueelle edellyttää sen tehtävän selkiinnyttämistä kunkin ammatin koulutuksessa tai jatkokoulutuksessa, varsinkin ihmissuhdeammateissa. Työnohjausta käsitellään oppimisprosessina jossa juuri prosessien tarkastelu kehittyy. Dynaamisen työnohjauksen oppimistavoitteita tarkastellaan lähinnä työnohjaajan tehtävien kannalta Fleming \& Benedekin mallin valossa. Esimerkkinä käytetään opettajankoulutusta, jossa tämänkaltainen työnohjaus koulutusvaiheessa edistäisi ammatillisen identiteetin kehittymistä. Lopuksi tarkastellaan lyhyesti ammatillisen roolin objektiivisia ja ammatillisen identiteetin subjektiivisia edellytyksiä ja asetetaan työnohjaus laajempaan, työyhteisö -yhteyteen.
\end{abstract}

Työ on ihmisen elämän tekemistä. Työikäiselle työyhteisöön kuuluminen, työssä onnistuminen, siinä oppiminen ja kehittyminen ovat tärkeitä tekijöitä aikuisiän kasvu- ja muutosprosessissa. Kokemus hallita omaa työtä on keskeinen, kuten myös mahdollisuus vaikuttaa työn muotoon ja luonteeseen.

Yhteiskunnassa joka teknologisoituu ja automatisoituu yhä enemmän, yhä useammat ihmiset kommunikoivat koneiden kanssa, näiden kielellä. Työn eri vaiheet saattavat olla erittäin nopeatempoisia. Mitä enemmän teemme työtä koneiden kanssa jotka suorittavat ihmisajattelun tapaisia toimintoja, ja jotka eivät (ainakaan toistaiseksi) reagoi emotionaalisesti, mutta joihin oma suhtautumisemme saattaa olla hyvinkin emotionaalinen, sitä tärkeämmäksi nousee tarve säilyttää ja kehittää ihmisten välistä kommunikaatiota. Itsensä ilmaiseminen ja ymmärretyksi tuleminen ja toisen ihmisen viestien tulkitseminen ja tajuaminen ei sensijaan ole nopeaa eikä itsestään selvää, mutta mielenterveyden kannalta tärkeämpää kuin koskaan kiihkeästi ja monella tasolla muuttuvassa yhteiskunnassa. (Sandelin 1984)

On ammatteja, joissa itse työn kohde on toinen ihminen, tai ryhmä ihmisiä, ja joissa juuri edellämainitun kaltaisten tietojen ja- taitojen hallitseminen on edellytys työn menestyksekkäälle suorittamiselle.
Psykologisia ja psykoterapeuttisia osia liittyy nykyään melkein kaikkeen koulutukseen jolla on psykologinen tai psykososiaalinen luonne. Niinpä esim. lastentarhaopettajat, opettajat yleensä, psykologit, kuraattorit, sairaanhoitajat, teologit, kodinhoitajat, sosionomit, jne. opiskelevat koulutuksensa yhteydessä erilaajuisia kursseja joiden tarkoitus on perehdyttää ammattiin valmistuvaa henkilöä ihmissuhde-kysymyksiin ja niiden hoitoon. Uusia ammatteja syntyy (esim. sosiaalikasvattaja) ja laajentunut työterveydenhuolto, päihdehuolto, aktiivinen perhehuolto ja lastenhuolto, kriminaalihuolto jne. on merkinnyt erityisammattiryhmien kasvua ja siten kasvavaa koulutuksen tarvetta juuri ihmissuhde-kysymyksissä.

Mutta ei ihmisten välinen vuorovaikutus korostu pelkästään huoltavissa ja hoitavissa ammateissa. Palveluammateissa toimivat henkilöt joutuvat muita useammin kohtaamaan ihmisiä, jotka ehkä lyhyenkin keskustelun aikana purkavat mieltään, suuttumustaan tai käsityksiään heitä palvelevalle henkilölle. Saattaa olla että purkautumisen kohdetta on 'etsitty', ja koska 'asiakas on aina oikeassa' voi tilanne muodostua hyvin epäsymmetriseksi ja palvelevaa henkilöä turhauttavaksi ellei hän voi tutkia tilannetta ja vuorovaikutusta lähemmin, esim. työnohjauksessa. Vaikka ihminen yleensä kek- 
siikin keinoja millä etääntyä painostavasta ja epäoikeudenmukaisesta tilanteesta (esim. vähättelemällä, itse suuttumalla, ylenkatsomalla jne.) vaikuttaa kuitenkin jatkuva itseen kohdistunut hyökkäys tai toisen ihmisen tunkeilevaisuus ennen pitkää jollakin tasolla - uni häiriintyy, esiintyy masennusta, päänsärkyä, lihasjännitystä tms.

Jopa sellainen ammattiryhmä kuin kirjastotyöntekijät, joita ei ensimmäiseksi ehkä yhdistä ongelmallisiin asiakastilanteisiin, voivat kokea työnsä erittäin raskaaksi; joskus suorastaan ylipääsemättömän vaikeaksi.

Sivukirjastot esim. Helsingissä ovat valoisia, viihtyisiä, lähes kodikkaita paikkoja. Nuoret, vailla paikkaa missä olla, tulevat näihin tiloihin vain ollakseen. Aaltoliikkeen tavoin eri sivukirjastot joutuvat eri vuosina kokemaan nuorten valloituksen. Kirjastonhoitajat huomaavat että he tarvitsevat enemmänkin nuorisotyöntekijän taitoja kuin hankkimaansa kirjastohoitajan pätevyyttä.

Työnohjauksessani on ollut ryhmä kirjastotyöntekijöitä joiden työtilanne oli muodostunut lähes kestämättömäksi. Heidän halunsa hoitaa työnsä hyvin ja palvella kaikkia kirjastonkäyttäjiä uhkasi kariutua siihen, että lähiön nuorisojengit häiritsivät kirjastonkäyttäjiä, rikkoivat kirjoja ja sisustusta, sekä ilkkuivat julmasti kirjastotyöntekijöitä. Hyvin pitkälle tämän kirjaston väki oli oppinut ymmärtämään näitä $12-17$ vuotiaita poikia ja tyttöjä, ja jopa keksimään keinoja joilla yhteiselo kirjastossa saatiin jotenkuten sujumaan. He olivat myös tajunneet epätoivon, yksinäisyyden ja toivottomuuden joka nuorten olemisesta huokui, ja osin myös ilmaisemaan ymmärtämyksensä. Kuitenkin juuri silloin nuorten heihin kohdistama iva ja julkeus, kuten kasvoihin sylkeminen, loukkasi heitä todella pahoin.

Työnohjauksessa näitä syntyneitä tilanteita tarkasteltiin, ja käsiteltiin sitä voimattomuuden tunnetta ja suuttumustakin, joka päivittäin heräsi työpaikalla. Vähitellen jokaiselle tuli mahdolliseksi vetää omat kestokykynsä rajat ja myös ilmaista nämä selvästi nuorille. Oli mahdollista osoittaa selvästi että ei hyväksynyt esim. kirjojen tärvelemistä jne., mutta että kirjastonhoitaja ei myöskään voi sitä estää jos roteva nuori uhmakkaasti ja järjestelmällisesti on repimässä kirjaa rikki. Nuoren oli näin pakko 'omistaa' tekonsa, ja joko jatkaa repimistä tai lopettaa - päätös teon jatkamisesta tai päättämisestä oli siirtynyt hänelle. 'Voimattomuuden' ilmaiseminen yhdessä teon paheksumisen kanssa realistisoi tässä tapauksessa tilanteen ja erottaa vuorovaikutussuhteessa olevat toisistaan niin, että nuori ei voi pitää aikuista 'vainoajana' tai teon 'perimmäisenä aiheuttajana'. Eikä kirjastotyöntekijän tarvitse tuntea epäonnistuvansa 'koska oikeastaan pitäisi saada nuori lopettamaan' juuri siksi että on aikuinen ja vastuussa kirjaston toiminnasta.

Olen yllä melko laajasti käsitellyt erästä esimerkkiä, jossa työnohjaus muodostui oman ammatin vuorovaikutussuhteita selventäväksi ja avartavaksi samalla vapauttaen työpaikan henkilökunnan toimimaan omien selvempien rajojensa puitteissa. Tässä mielessä työnohjauksen voi ymmärtää lisäkoulutuksena henkilöille joille ammatillinen koulutus ei tällaisia valmiuksia ollut tarjonnut - ja miksi olisikaan!

\section{Työnohjaus käsitteenä}

Työnohjauksen (supervision) systemaattinen käyttö osana ammatillista koulutusta alkoi 1920-luvulla Berliinin psykoanalyyttisen instituutin psykoterapeuttisessa koulutuksessa (Fleming \& Benedek 1983,6). Psykoterapeuttisen koulutuksen alueella työnohjausta ja työnohjauksessa/tapahtuvaa oppimista on myös tähän saakka ehkä eniten tutkittu (kts. esim. Fleming \& Benedek 1966; Matarazzo 1978; Langs 1979; Hess 1980; Ekstein \& Wallerstein 1980 ym). Myöhemmin käsite työnohjaus (handledning) on saanut laveamman käsitesisällön. Esimerkiksi opettajankoulutukseen kuuluva 'työnohjaus' on enemmänkin instruktiota, arvostelua, ohjaavan opettajan oppilastaan korjaava valvomista. Tästä ehkä johtuukin että työnohjauksella on opettajien keskuudessa melko negatiivinen sointu, pääasiassa siihen liittyvän opetuksen arvostelun johdosta. Sinikka Ojanen (1985) on ansiokkaalla tavalla pyrkinyt selkiinnyttämään opettajien työnohjauksen sisältöä ja sen mahdollisuuksia kasvattajan tukena. Inkeri Sava (1985) puolestaan on raportoinut kiinnostavalla ja syvällisellä tavalla kahdesta työnohjausryhmästä, joihin osallistuivat yhden lukuvuoden ajan erityisopettajien koulutuksessa olevat opettajat. Kysymyksessä oli siis klassiliinen työnohjaus (supervision) ryhmässä joka on jatkuva, yhden työnohjaajan kanssa tapahtuva tavoitteellinen prosessi.

Keskeisenä ajatuksena työnohjauksessa on aikaansaada kokemusperäinen oppimistilanne jossa oppija oppii enemmän itsestään, suhtees- 
taan työhön, organisaatioon jossa työnsä suorittaa, sekä ennenkaikkea suhteestaan asiakkaisiinsa (oppilaisiinsa, potilaisiinsa) kokeneemman ohjaajan opastuksella, harjoittaessaan ammattiaan. Asetelma muistuttaa paljon vanhaa mestari-kisälli suhdetta, kuten Hyyppä $(1983,4)$ huomauttaakin. Suurin ero on kuitenkin siinä että työnohjaaja ei toimi 'ylhäältä alas'. Työnohjaussuhde on kahden tai useamman aikuisen vuorovaikutussuhde, ja siten aina symmetrinen.

Työnohjaus on sittemmin levinnyt psykiatrian ja psykoterapian alueelta yhä useammalle ammatilliselle alueelle, ja on nykyään luonnollinen osa työssä-oppimista (on the job learning) monessa ihmissuhdeammatissa - useimmiten kuitenkin vasta peruskoulutuksen jälkeen.

Ammattialueesta riippuen on työnohjauksesta esitetty erilaisia määritelmiä. Valaisevia esityksiä ovat tehneet esim. Sava (1985), Ojanen (1985) sekä Siltala, Kauttu et al. (1982). Mielestäni Ojanen $(1985,58)$ on hyvin luonnehtinut opetusalan työnohjauksen luonnetta:

"Työnohjaus on syväsuuntainen, kokemusperäinen oppimisprosessi. Se on oppimista kokemuksen ja vuorovaikutuksen avulla. Se on myös

a) elävällä kuuntelevalla tavalla osallistumista ryhmässä,

b) työtaidon kartuttamista sekä

c) henkisen kuormituksen keventämistä."

Hyypän $(1983,4)$ määritelmä on laajempi ja edellyttää (arvelisin pääsääntöisesti) ohjaajan olevan saman ammatin edustaja kun työnohjauksessa olevat.

\section{"Työnohjaus on oppimissuuntautunut vuorovaikutusprosessi, jossa suuremman ammatillisen kokemuksen tai tietämyksen omaava henkilö asettaa ammattitaitonsa palvelemaan toisen työntekijän ammatillis- ta kasvua."}

Näin työnohjaus asettuu selvästi omalle tehtäväalueelleen jonka suhdetta sim. konsultaatioon ja psykoterapiaan (joksi työnohjausta usein luullaan; tosin se voi toimia hyvinkin eheyttävästi kokonaispersoonallisuuden kannalta vaikka keskustelun kohde on ohjattavan työkokemus) Hyyppä $(1983,11)$ on kuvannut seuraavalla kuviolla, jota olen täydentänyt opettajankoulutuksen erityisellä 'työnohjauksella'.
Kuvio 1. Työnohjauksen suhde konsultaatioon, psykoterapiaan sekä opettajankoulutukseen 'työnohjaukseen'

\section{TEHTÄVÄ}

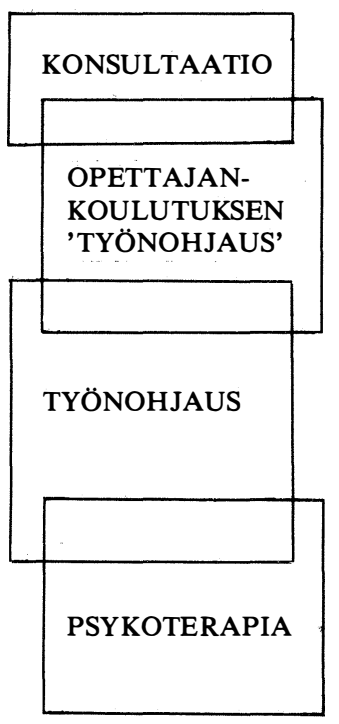

\section{Asiantuntemuksen hyväksikäyttơ ongelmien hahmottamisessa. \\ Oppijan tyőharjoittelun ohjaus, korjaus ja arvostelu. Opiske- lun erityinen vaihe.}

Ongelmien tietoinen henkilökohtainen ja tunneperäinen tutkiminen.

\section{Itseä ja tyőtä koskevan avoimuu- den kehittäminen.}

Tiedostamattoman tason henkilokohtaisen problematiikan tutkiminen.

Oivalluksen ja syvemmän tietoisuuden kehittyminen.

Myös Ojanen $(1985,69)$ painottaa työnohjauksen keskittymistä yksilön työrooliin suhteessa työorganisaatioon. Koska ihminen kuitenkin toimii ja elää jakamattomana kokonaisuutena, toimivat kaikki hänen persoonallisuutensa alueet työnohjauksen oppimisprosessissa, ja ehkä perusteellisemmin ja syvällisemmin kuin muussa opetuksessa koska kaikki käsiteltävä, analysoitava ja opittava on oppijasta itsestään lähtöisin.

Kokemusperäinen, elämyksellinen oppiminen, jossa omaa roolia tutkitaan, tarjoaa myös ohjattavalle mahdollisuuden havainnointi- ja analyysikyvyn kehittämiseen jolla on merkitystä ja josta on hyötyä myös varsinaisen työtilanteen ulkopuolellakin.

Hyyppä $(1983,42)$ on esittänyt mallin tällaisesta syklisestä kokemusperäisestä oppimisesta joka perustuu Jones \& Pfeifferin (1980) ajatuksiin. Sava $(1985,43)$ on vuorostaan täydentänyt mallia Engeströmin $(1982,60)$ oppimisvaiheita kuvaavan mallin avulla. (Kuvio 2.)

Loppujen lopuksi on kyse hyvinkin luonnollisesta tapahtumasta joka jatkuvasti toistuu jokaisen ihmisen arkipäiväisessä elämässäkin. Jotain tapahtuu meille, ja voidaksemme hahmottaa, rajata ja ymmärtää tapahtunutta, se- 


\section{MOTIVOINTI}

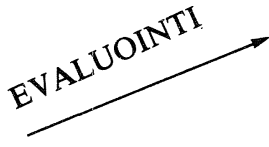

5) Soveltaminen

entistä tehokkaamman

toimintamallin suunnittelu

ja toiminta sen mukaan)

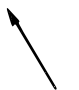

4) Yleistäminen

(johtopäätösten tekeminen

'todelliseen elämään')
1) Kokemus

(toiminta, tekeminen, "tapahtuma", koettu ongelma jne.)

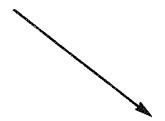

2) Julkistaminen

(havaintojen, reaktioiden, heränneiden tunteiden jne. jakaminen)

3) Prosessointi

(keskustelu tapahtumasta, sen dynamiikasta, kokemuksen hahmottaminen)

\section{SISÄISTÄMINEN}

kä sen jälkeen toimia parhaalla mahdollisella tavalla, useimmat ihmiset tekevät juuri kuten mallissa kuvataan. Kertovat tapahtuneesta jollekulle, miettivät syitä ja seurauksia. Pyrkivät löytämään ratkaisun koettuun ongelmatilanteeseen. Ja toimivat senjälkeen parhaan kykynsä mukaan.

Hyyppä $(1983,5)$ ilmaisee asian seuraavasti: "Työnohjauksen väline on ohjaajan ja ohjattavan välinen keskustelu. Sopimuksen mukaan he tapaavat säännöllisesti ja puhuvat jälkimmäisen työstä. Keskustelut perustuvat vapaaehtoisuuteen ja luottamuksellisuuteen. Tavallisesti ohjattava on hoitanut työtään jo monia vuosia."

\section{Työnohjauksen pedagoginen tavoite}

Mikä sitten erottaa professionaalisen työnohjauksen tavanomaisesta pohdiskelusta ystävän kanssa?
1. Työnohjaajalla tulee olla selvä pedagoginen tavoite jonka hän perustaa pedagogiselle diagnoosille.

2. Ohjattavan oman kokemuksen ja työtilanteen havainnointi, kokemusten ilmaiseminen ja johtopäätösten tekeminen tulee ohjattavalle yhä tiedostetummin työskentelytavaksi (joka on hänen minänsä käytössä tietenkin muulloinkin kuin työnohjauksessa).

Tapaa, jolla ohjattava lähestyy todellisuutensa ilmiöitä voisi kutsua vaikka hermeneuttiseksi esim. Radnitzkyn (1970,43-44) tapaan. Tämän havainnoinnissa tapahtuvaan psyykkisen 'liikkeen' voi kuvata kuten alla. (Kuvio 3.)

Itsensä ymmärtäminen ja omien tarkoitusperiensä tajuaminen (Selbsverständniss), sekä 'toisen' (potilaan, asiakkaan, oppilaan, luokan) ymmärtäminen (Fremdverständniss) ja näiden kahden 'tilan' välillä liikkuminen avaa mahdollisuuden hetkelliseen etääntymiseen, välimatkaan (Verfremdung), jolloin työ- tai

Kuvio 3. Subjektiivisten kokemusten hetkellinen 'objektivointi' hermeneuttiseen tapaan

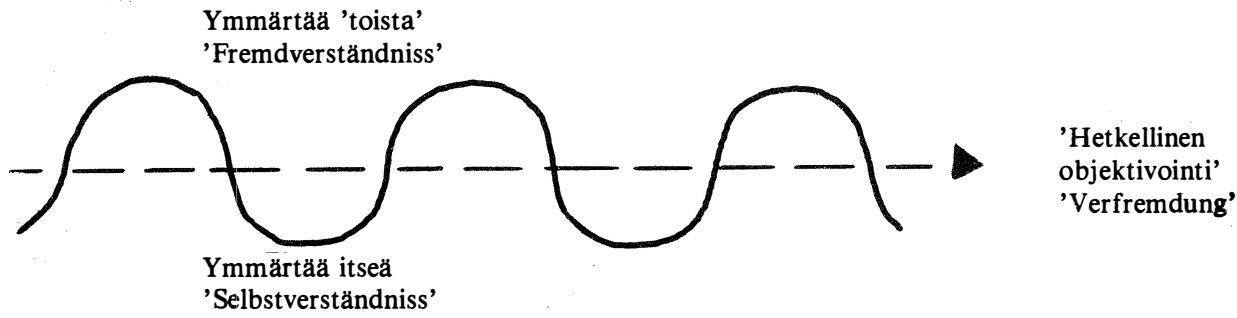


ongelmatilannetta on mahdollista tarkastella vapaammin, eri tahoilta - ei pelkästään 'minän' näkökulmasta.

Työnohjaus on siis vuorovaikutusprosessi, jonka turvalliseksi järjestetyissä puitteissa, ohjattava oppii itsensä ja omien vuorovaikutussuhteittensa havainnointia ja analyysia sekä eläytymistä oman ja toisten toiminnan perusteisiin. Prosessi edellyttää ohjattavan samanaikaista sekä intellektuaalista että emotionaalista aktiviteettia ja edistää edetessään ammatillisen identiteetin selkiintymistä ja siten myös ammatillista pätevyyttä ja ammatillisia valmiuksia.

On kiinnostavaa todeta, että työnohjausprosessin oppimiskulkua tarkasteltaessa meillä on osaksi toisenlainen käsitteistö käytettävissämme kuin opettamisesta puhuttaessa.

'Motivointi' on opetuksessa usein käytetty termi. Mitä se loppujen lopuksi merkitsee on minulle epäselvää. On esim. vaikeaa täsmällisesti osoittaa miten se tapahtuu, mitä aspektia ihmisessä tulee lähestyä. Onko eri tyyppistä motivointia eri tyyppisiin ei-motivoituihin tilanteisiin jne? Käsitykseni mukaan 'motivaatio' ja 'motivointi' ovat ainakin opetuksessa 'hätätermejä' joihin on ollut pakko tarrautua kun ei ole tiedetty miten menetellä jos oppilaat eivät suostu olemaan onnistuneita oppilaita. Eli kahdeksan tunnin ajan kiinnostuneita, aktiivisia, oppivaisia, muistavaisia, älykkäitä, nopeita jne.

Olen toisessa yhteydessä (Sandelin 1981, 62-64) todennut, että olisi luultavasti huomattavasti hedelmällisempää tutkia niitä vastarinnan ilmiöitä joita oppimisen yhteydessä esiintyy. Vastarinta eli resistanssi on psykologian alueella tutkittu ja käyttökelpoinen käsite, joka esim. työnohjauksessa mahdollistaa oppimista estävien tai hidastavien esteiden tunnistamista. Tällöin ohjaaja ja ohjattava voivat yhdessä tarkastella miksi juuri jossain määrätyntyyppisessä tilanteessa ohjattava saattaa tulla 'sokeaksi' tai 'kuuroksi' tai miksi ohjaajan jokin tarkastelua selventävä kommentti ei mene 'perille'. Ohjattavalle voi käydä selväksi että hän muissakin samanḱaltaisissa ja -sisältöisissä tilanteissa yleensäkin tekee niin. Tiedostamisen ja tajuamisen myötä voi myös este poistua.

\section{Työnohjaajan tehtävä}

Työnohjaajan tehtävää on lähestytty monella tasolla. Keskeinen on yhteinen näkemys siitä että työnohjaajan suhde omaan itseensä tulee olla selvä ja mahdollisimman selvitetty. Tarjoaahan työnohjaajana oleminen 'tajuttomalle' ihmiselle oivallisen tilaisuuden oman paremmuuden esittelyyn, vallan käyttöön ja indoktrinaatioon, kuten kaikissa opettajatyyppisissä ammateissa. Työnohjaaja ei siis koskaan ole saarnaaja, arvostelija tai pidä itseään ainoana ideaali-esimerkkinä. Hänessä tulee päinvastoin esiintyä juuri se tutkiva, harkitseva ja ymmärtävä lähestymistapa josta vähitellen muodostuu ohjattavan ja ohjaajan yhteinen työskentelytapa ja 'metodi'. Siinä suhteessa hän tietenkin toimii esimerkin tavoin, ja hänen tuleekin olla tästä tietoinen.

Käsitykset vaihtelevat siitä tuleeko työnohjaajalla olla sama ammatti kuin ohjattavilla että hän siis edustaisi alaa vanhempana, kokeneempana. Psykoterapeuttisessa työnohjauksessa tämä on vaatimus. Muissa hoitotyöhön liittyvissä ihmissuhdeammateissa käytäntö vaihtelee - usein siten että psykoterapeuttisen koulutuksen saanut ('vuorovaikutussuhdeekspertti') ohjaa esim. mielisairaanhoitajia, kuraattoreja, sosionomeja jne. Tai näiden ammattiryhmien edustajat hankkivat sekä psykoterapeuttisen että työnohjauskoulutuksen.

Kun ohjattavan ammatti ei varsinaisesti liity hoitotyöhön, mutta jossa työpanos nimenomaan edellyttää vuorovaikutussuhdetta, ei työnohjaajan välttämättä tarvitse olla alan ammatti-ihminen. Sensijaan työnohjauskoulutus on tarpeellinen (jota Suomessa ei liiemmälti ole toistaiseksi). Ohjaajan ammatillinen pätevyys painottuu tällöin työn dynaamisten näkökohtien tarkasteluun, koska ohjattavakin yleensä esittää työstään lähinnä ne puolet tai tilanteet jotka koetaan ongelmalliseksi tai vaikeasti hallittaviksi. Ohjattavan kautta työnohjaajalle muodostuu kuva työstä sellaisena kuin ohjattava sen näkee ja kokee. Mitään täydellisen 'objektiivista' kokonaiskuvaa ei tarvitakaan, sillä ohjattavan esittämä on hänen todellisuutensa, ja vain hän voi myös siihen saada aikaan muutoksia. (En nyt tarkoita laajempia organisatorisia tai rakenteellisia työpaikan muutoksia).

Mielestäni tällä lähestymistavalla on huomattavat edut. Työnohjaaja joutuu todella keskittymään (kuuntelemaan, ymmärtämään) ohjattavaa koska todellisuus välittyy hänen kauttaan. Tuntematta tarkoin koko työkenttää voi myös nopeammin havaita jos ja koska ohjattava pyrkii toistamaan viitteellisesti työnohjausprosessissa niitä ajatusmalleja ja toimintamuotoja joilla hän, ehkä menestymättä, kohtaa ongelmia työsuhteissaan. Ne piirtyvät selvemmin toistuviksi kuvioiksi yhteistyön puitteissa kun molemmilla ei ole eksplisiittisesti samaa ammatillista kokemustaustaa johon ne 
muuten saattaisivat 'upota'.

Työnohjaukseen liittyy siis myös käsitys että ihminen kaikissa vuorovaikutussuhteissaan, eräässä mielessä, 'toistaa' itseään. Jos jokin tilanne esim. koetaan uhkaavana, on hänellä määrätty toimintamalli jonka avulla hän, enemmän tai vähemmän tarkoituksenmukaisesti, pyrkii kohtaamaan/välttämään uhan. Koska työnohjaus on moniulotteinen prosessi, ehtii ohjattava senkin aikana kokea monta erilaista mielentilaa - tyytyväisyyttä, pelkoa, iloa, uhkaa jne. Vuorovaikutuksessaan ohjaajan (ja ryhmän) kanssa ja vastaavasti selostuksissaan työstään hän kertoo ja oivaltaa kuinka hän näitä moninaisia tilanteita kulloinkin käsittelee, tai haluaisi käsitellä.

Työnohjaus-työ -suhdetta ohjattavan kannalta voidaan kuvata kuten alla.

Kuvio 4. Ohjattavan kaksi roolia/tehtävää, joita kumpaakin voidaan tarkastella työnohjauksessa

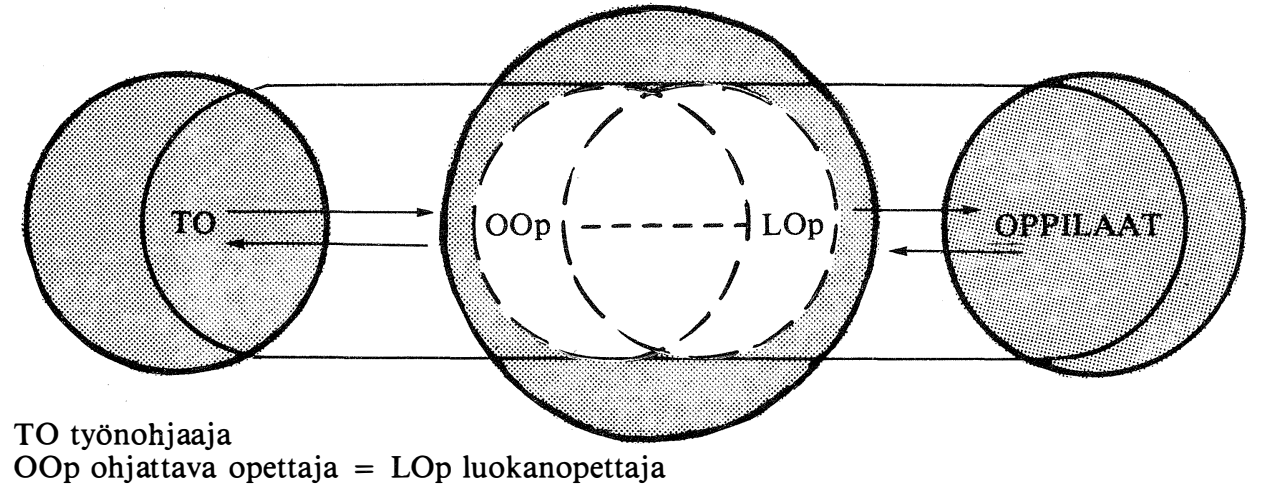

Työnohjaukseen osallistuva esim. opettaja on sekä 'ohjattava opettaja' että työssään 'luokanopettaja'. Oppilaisiinsa nähden hän on auktoriteettisuhteessa (tai ei ole). Työnohjaajaan hän voi tuntea olevansa oppilassuhteessa (tai ei tunne). Jokaisessa variaattiossa hän ilmentää tapaansa suhtautua 'oppilaaseen' ja 'auktoriteettiin' - erääseen työnsä keskeiseen kysymykseen; joskus myös ongelmalliseen sellaiseen.

Molemmille rooleille antaa kaikupohjan aikaisemmat kokemukset, ihmiskäsitys, maailmankuvan kielteisyys tai myönteisyys jne (harmaa alue). Sama koskee tietenkin sekä työnohjaajaa että oppilaita tässä esimerkissä - hekin toimivat omaa kokemus/kasvatustaustaansa vasten. Työnohjaajan on vain tunnettava omansa paremmin kuin muut.

Työnohjaajan tärkein tehtävä työnohjauksen alkaessa on luoda tulevalle työskentelylle hyvät edellytykset. Sekä työnohjaajan että ohjattavan on hyväksyttävä yhteinen kasvatuksellinen tavoite/tarkoitus alkavalle työlle. Työnohjaus on aina työsuhde - ei opettaja-oppilas suhde eikä psykoterapeutti-asiakas/potilas suhde, kuten jo aikaisemmin mainitsin. Tavoite voi olla esim. "'tulla paremmaksi opettajaksi", tai "'selvittää ongelmalliset henkilösuhteet työpaikalla", tai "uskaltaa jatkaa ja mennä eteenpäin valitussa ammatissa" jne. Tämä molempien hyväksymä tavoite muodostaa perustan n.s. oppimisalliansille, oppimisliitolle. (Fleming \& Benedek 1983,53)

Oppimisliitto merkitsee käytännössä että sekä työnohjaaja että ohjattava(t) tahtovat työskennellä kohti edukatiivista tavoitetta. Se ilmenee kommunikaatiokyvyssä itse työnohjauksessa (ohjattava pyrkii kuvaamaan ja ilmaisemaan kokemuksiaan ja käsityksiään sekä tarkastelemaan niitä, vaikka se ei aina kovin helppoa olisikaan). Se ilmenee myös osallistujien halussa ymmärtää ja eläytyä toistensa kokemuksiin ja näin muodostaa intellektuaalisen ja emotionaalisen kaikupohjan joka edesauttaa oman tajuamisen kehittymistä.

Oppimisliitto, ja sen kautta kasvava luottavainen ja turvallinen ilmapiiri, saattaa työnohjauksen aikana vaihdella ja jopa heiketä. Tähän vaikuttavat $\mathrm{mm}$. ohjattavan ristiriitaiset tunteet (hän voi ajoittain pitää ohjaajaa liian ohjaavana, ymmärtämättömänä tms.). Tällöin työnohjaajan tulee tietenkin tarkistaa oma asenteensa, ja esim. onko ohjattava ehkä oikeassa, ennenkuin ryhtyy tutkimaan tilannetta ohjattavan 'tavanomaisena toimintamallina'. Jos oppimisliitto puuttuu tai heikkenee liikaa saattaa ohjattava vain 'liukua' läpi työnohjauksen - vähätellä työtä siellä, toistaa sa- 
moja asioita, myöhästellä jatkuvasti, kieltäytyä yhteistyöstä eri keinoin jne. Hyyppä $(1983,70)$ nimittää tätä pseudoprosessiksi. Pahimmassa tapauksessa työnohjausprosessi voi kokonaan keskeytyä ennenkuin ohjattava on oivaltanut oman reaktionsa syyn.

\section{Työnohjauksen pedagoginen luonne}

Työnohjaajalta vaadittavat tiedot ja taidot voidaan määritellä monella tavalla. Yleensä lähtökohtana on se mihin kohtaan jatkumoa opettaminen vs. kasvu määrittelijä sijoittaa työnohjauksen tehtävän. Edellä olen hahmotellut työnohjausta jota lähinnä voisi kutsua dynaamiseksi ja kasvusuuntautuneeksi. Tämä näkemys ohjaa myös käsitystäni ohjaajan tehtävistä. Fleming \& Benedek $(1983,68)$ ovat esittäneet mallin työnohjaajan tehtävistä psykoanalyyttisessä koulutuksessa. Olen eräiltä osin muunnellut mallia kuvaamaan yleistä dynaamista työnohjausta erityisesti opettajankoulutuksessa. (Kuvio 5.)

Määritellyn päämäärän pohjalta työnohjaaja avustaa ohjattavaa kehittymään analyyttisenä instrumenttina niin että ohjattavan itsehavainnointi- ja reflektointikyky kasvaa ja sen myötä yksilöllinen ammatillinen identiteetti.

Pedagogisen diagnoosin perusteella työnohjaaja evaluoi ohjattavan kommunikaatiokykyä, sekä taitoa havaita opetusprosessin osia ja kokonaisuutta, sekä mm. tiedostamista reaktioistaan työnohjausprosessissa ja suhteessaan ohjaajaan.

Koska oppimisen tavoitteena on opetustilanteen (ja työnohjaustilanteen) dynaamisen luonteen tajuaminen, opetuksen tekniikan ja teorian tukemana, työnohjaaja orientoi ohjattavaa esim. tämän vaikutuksesta oppilaisiin, kolleegoihinsa jne. niiden tilanteiden ja kokemusten valossa jotka muodostavat työnohjausprosessin 'materiaalin'.

Kuvio 5. Malli työnohjaajan tehtävistä (Fleming \& Benedek'in mallista muunneltuna)

\section{PÄÄMÄÄRÄ}

1. Edistää opet.toimintaa opetustilanteessa

2. Edistää opet. toimintaa kolleegana ja organisaat. jäsenenä.

3. Oppimisen objektivointi.

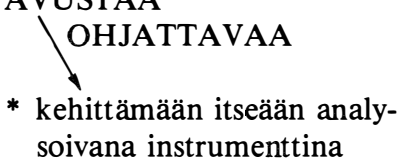

* havainnointi- ja itsereflektointikyvyn kehittämisessä

* kehittämään selvän ammatillisen identiteetin
PEDAGOGINEN DIAGNOOSI

1. Eläytyminen oppilaiden tilanteeseen.

2. Prosessien ymmärtäminen.

3. Kommunikaatio- ja artikulaatiokyky.

4. Eläytyminen ja kommunikaatiokyky työnohjauksessa.

EVALUOI OHJATTAVAN

* itsehavainnointi- ja kommunikaatiokykyä omien motiivien suhteen

* kykyä vaihdellen tarkastella osia ja kokonaisuutta

* tajuamisen tason

* tiedostamiskyvyn reaktioistaan suhteessa työhön, ohjaajaan, ja työnohj. osallistuviin

\section{OPPIMISTAVOITE}

1. Opettaja-oppilas prosessin dynamiikan tuntemus.

2. Työnohjausprosessin dynamiikan tajuaminen.

3. Yleinen ja erityinen tekniikka.

4. Yleinen ja erityinen teoria.

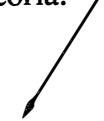

ORIENTOI OHJATTAVAA

* tämän vaikutuksesta oppilaisiin

* tämän implisiittisistä tai epäselvistä motiiveista työssä toimiessaan

* relaatioista oppilaisiin, kolleegoihin ja organisatioihin

* relaatiosta työnohjaajaan ja toisiin ohjattaviin 
Näin lueteltuina työnohjaajan tehtävät voivat vaikuttaa mekanistisilta ja vähemmän empaattisilta mitä aiemmin esitetty teksti antaisi aiheen odottaa. Juuri siksi että työnohjaus, yhtälailla kuin opetustilannekin, on niin moniulotteinen ja vaikeasti määriteltävissä, on silläkin uhalla että prosessin 'soljuvuus' mallin staattisessa kuvauksessa heikkenee, pyrittävä löytämään sanoja joiden avulla on mahdollista lähestyä ja kuvata tai tutkia työnohjauksessa tapahtuvaa oppimista. Samoin on työnohjauksen vuorovaikutukseen sisältyvän 'opettamisen' piirteitä pyrittävä jäsentämään.

Työnohjaajan pääasiallinen työskentelymalli on orientoiminen.

Fleming \& Benedek'in $(1983,73)$ mukaan tämä käsittää seuraavat enemmän jäsennellyt toimintamuodot:

- klarifikaatio, selventäminen

- demonstraatio, osoitus

- instruktio, ohje sekä joskus

- konfrontaatio

Jos ohjaaja esimerkiksi opettajan kohdalla voi olettaa pedagogisen diagnoosin perusteella että tämä on 'sokea' kahdella, toisiinsa liittyvällä, alueella kuten

\section{eläytymiskyky + itsehavannointi \\ esim. oppilaan ongel- esim. omien tarkoitus- miin perien epätarkka tunte- minen}

voi tämä ilmetä monella eri tavalla hänen työssään. Työnohjauksessa esimerkkiopettajamme saattaa antaa seuraavanlaista informaatiota:

- väritön, 'litteä' selostus opettaja-oppilas suhteesta

- epätäydellinen, tai vain jotain erityistä kohtaa alleviivaava selostus opettaja-oppilas tilanteesta

- suuri määrä oletuksia, mielikuvia, käsityksiä miksi näin on käynyt, jne.

Tässä yhteydessä on syytä huomauttaa, etä pedagoginen diagnoosi ei suinkaan ole arvosteleva; vain toteava. Se voidaan esittää olettamuksena tai hypoteesinä myös ohjattavalle jos kestävä oppimisallianssi on kehittynyt. Kaiken aikaa työnohjaaja on todella ohjattavan 'liittolainen'; työskenteleväthän he yhteistä päämäärää kohti - ohjattavan päämäärää jonka saavuttamisessa työnohjaaja voi häntä avustaa.

\section{Sittenkin - miksi työnohjausta?}

Ihminen joutuu (yleensä) työssään toimimaan yhdessä toisten ihmisten kanssa. Ihmistenvälisen yhteistoiminnan edellytykset voidaan määritellä. Humble \& Janson (ei päivätty teos) tunnistavat sekä objektiiviset että subjektiiviset edellytykset.

Objektiivisia edellytyksiä ovat mm. työtehtävän luonne, eli miten selkeästi tehtävän tavoite, sitä koskeva 'teoria' sekä työmetodit on artikuloitu ja määritelty. Toiseksi voimme määritellä objektiiviset, ulkoiset yhteistoiminnan edellytykset. Näihin kuuluu työn organisointi, resurssit, henkilökunnan kokoonpano ja vaihtuvuus jne. Kolmanneksi on edellytykset jotka vaikuttavat molemminpuoliseen tuntemukseen, eli se kuinka selvästi työtehtävä ja sen funktio on määritelty suhteessa yhteistoiminta-alueeseen; metodit yhteistoiminnan suorittamiseen; koulutus ja pätevyys jne. (Humble \& Jansson, 7).

Mikäli nämä ulkoiset, nk. objektiiviset yhteistoiminnan edellytykset ovat selvästi rajattavissa ja määriteltävissä voimme sanoa että on mahdollista tunnistaa määrätty professionaalinen, ammatillinen rooli.

Tämä ei kuitenkaan vielä merkitse että roolin haltijalla olisi rooliin sopiva ammatillinen identiteetti. Humble \& Janson $(7,34-37)$ ovatkin pohtineet mitkä subjektiiviset edellytykset on täytettävä jotta ammatillinen identiteetti voi kehittyä, ja niin että sen suuntaus on enemmän tehtäväkeskeinen kuin itseen suuntautuva, 'itse-keskeinen'.

Yksilötasolla voimme tällöin analyyttisesti erottaa kognitiiviset ja affektiiviset edellytykset yhteistoiminnalle. Kognitiiviset koskevat sitä missä määrin yksilö on tiedostanut ja hänellä on faktista tietoa ammatillisesta roolistaan. Kutsumme tätä pätevyyden aspektiksi. Affektiivisilla edellytyksillä tarkoitetaan missä määrin yksilön henkilökohtaiset ja ammatilliset intressit ovat sopusoinnussa keskenään. Tätä voimme kutsua valmiuden aspektiksi. Humble \& Jansonin (7) mielestä voimme siis ammatillisen identiteetin elementteinä nähdä a) pätevyyden roolin täyttöön ja b) valmiuden toimintaan roolissa.

Jotta ammatillinen identiteetti olisi pääasiassa tehtäväkeskeisesti suuntautunut, tulee työn tyydyttää yksilön kohdalla 1) persoonallinen aspekti - tyytyväisyys oman työpanoksen laatuun ja määrään, 2) ihmistenvälinen aspekti - 
työyhteisön kannustus ja hyväksyntä ammatillisessa roolissa, sekä 3) funktionaalinen aspekti - realismi ja tyydytys oman työn yhteiskunnallisesta merkityksestä.

Myönteisten edellytysten vallitessa voimme olettaa että yksilö

1) tuntee täydentävänsä suhdetta vuorovaikutuksessa olevaan

2) on avoin partnerin yksilölliselle osuudelle

3) tuntee kiinnostusta omaan työyhteisöönsä

4) on realistisesti osallistuva työyhteisön toimintaan

5) tuntee kiinnostusta myös muiden roolitehtäviä kohtaan

Kielteisten edellytysten vallitessa voimme olettaa että

1) syntyy kilpaileva suhde partneriin työyhteisössä

2) esiintyy torjuntaa ja sulkeutuneisuutta partnerin yksilöllisyyttä ja tehtävää kohtaan

3) syntyy riippuvuutta omaan työryhmään

4) antaa periksi tai masentuu tai on epärealistisesti osallistuva

5) haluaa tietoa muista yksityishenkilöinä (Humble \& Janson, 8)

Ylläolevasta listasta käy jo ilmi että kielteisten edellytysten ryhmässä on juuri sellaisia ongelmiksi koettuja aspekteja joita hyvinkin usein työnohjauksessa käsitellään - pyritään selventämään, rajaamaan ja löytämään ammatilliselle identiteetille selkeämpi ja yksilöä tyydyttävä sisältö.

Työnohjauksessa lähdemme siis dynaamisesta näkemyksestä psyykkisten ilmiöiden luonteesta. Ihmisen kokemusmaailmassa on löydettävä synteesi mielikuvaelementin ja affektiivisen elementin välillä. Ihmisen varhainen identiteetin kehitys kulkee mitättömyyden, avuttomuuden ja riippuvuuden kokemusten läpi tahdon ja itsenäistymisen kautta kohti yksilöllistä asennetta ja elämäntyyliä joka on paljon enemmän kuin opittu rooli. Suotuisa kehitys johtaa yksilön ja ympäröivän maailman suhteeseen jolle on tunnusomaista sekä pätevyys että luottamus, sekä yksilöllisyys että halu kuulua yhteen ja integroitua muiden kanssa. Samalla tavoin on ammatillinen identiteetti määritelty kokonaisuudeksi joka sisältää sekä tahdon että pätevyyden, tyydytyksen siitä että tehtävä on suoritettavissa, ja tyydytyksen siitä että tehtävän suorittaa "juuri minä'. (Humble-\& Janson, 35)

Työnohjauksessa on näin ollen kysymys jos vielä vertaamme siinä tapahtuvaa kehitystä varhaiseen kehitykseen - professionaalisesta sosialisaatiosta jossa kehittyy ammatillinen identiteetti. Työnohjausprosessissa aktivoituu ohjattavan itsekuva ja itsekäsitys, hänen maailmankuvansa sekä jotain mitä voisimme kutsua vaikka persoonalliseksi oppimisfilosofiaksi joka koskee yksilön käsitystä oppimisen/muutoksen tarpeellisuudesta ja tulosten saavutettavuudesta. Jos kestävä oppimisliitto on kehittynyt voi työnohjauksessa olevan kokemus olla sekä avartava, vapauttava ja häntä tyydyttävä.

\section{Kirjallisuutta}

Ekstein, R. \& Wallerstein, R. 1977. Handledning och utbilding i psykoterapi. Stockholm: Natur och Kultur (New York: Basic Books 1985)

Engeström, Y. 1982. Perustietoa opetuksesta. Helsinki: Valtion Painatuskeskus.

Fleming, J. \& Benedek, T.F. 1983. Psychoanalytic Supervision: A Method of Clinical Teaching. New York: International Universities Press.

Hess, A. 1980. Psychotherapy Supervision. Theory, Research and Practice. New York: Willey.

Humble, K. \& Janson. U. (Odat.) Utkast till en teori om samverkanbetingelser. Stockholms läns landsting. Sociala nämnden. Metodutvecklingsgruppen. Rapport 6.

Hyyppä, H. 1983. Avointen järjestelmien teoria työnohjauksen viitekehyksenä. Oulun yliopiston kasvatustieteiden tiedekunnan tutkimuksia. $17 / 1983$.

Jones, J.E. \& Pfeiffer, J.W. 1980. Annual Handbook for Group Facilitators. University Associates. Mainittu teoksessa: H. Hyyppä 1983.

Langs, R. 1970. The Supervisory Experience. New York: Jason Aronson.

Matarazzo, R.G. 1978. Research on the Teaching and Learning of Psychotherapeutic Skills. In: S. Garfield \& A.E. Bergin (Eds.) Handbook of Psychotherapy and Behaviour Change. 2nd edition. New York: Wiley.

Ojanen, S. 1985. Opettajien työnohjaus kasvattajan tukena. Espoo: Weilin \& Göös.

Radnitzky, G. 1970. Comtemporary Schools of Metascience. Copenhagen: Munksgaard/Scandinavian University Books.

Sandelin, S. 1981. 'Self' and Education. Commentationes Scientiarum Socialium. Societas Scientiarum Fennica. Helsinki.

Sandelin, S. 1984. Ihminen työn kohteena - näkökulmia mielenterveystyön koulutukseen. Teoksessa: K. Pylkkänen, Mielenterveystyön koulutuksen ja työnohjauksen kehittämistarpeet ja mahdollisuudet. Lääkintöhallitus. Julkaisuja 46. Helsinki.

Sava, I. 1985. Työnohjaus opettajien tietoisuuden kasvun välineenä. Tapaustutkimus kahdesta työnohjausryhmästä. Helsingin yliopiston opettajankoululaitos. Tutkimuksia 31 .

Siltala, P., Kauttu, K., et al. (toim.) 1982. Työnohjaus terveydenhuollossa ja opetustyössä. Espoo: Weilin \& Göös. 